\title{
PENGEMBANGAN TECHNO VIRTUAL BERBASIS WEBSITE SEBAGAI MEDIA PEMBELAJARAN REKAYASA VISUAL BLENDER 3D BAGI MAHASISWA DESAIN PRODUK
}

\author{
Baskoro Suryo Banindro \\ Institut Seni Indonesia (ISI) Jogja \\ banindro@gmail.com
}

\begin{abstract}
Abstrak
Penelitian terapan ini bertujuan untuk mengembangkan model pembelajaran alih media teknologi maya (techno virtual) rekayasa visual Blender 3D bagi mahasiswa berbasis website learning. Secara operasional penelitian ini akan menilai apakah melalui techno virtual, materi bahan ajar dapat dengan mudah diterima dan membantu para mahasiswa dalam menyelesaikan tugasnya. Penelitian ini menggunakan pendekatan deskriptif kuantitatif, yaitu penelitian yang mendasarkan atas pengolahan statistik, dan percobaan terkontrol dengan sampel mahasiswa desain produk. Metode analisis yang digunakan yaitu analisis inferensia berdasarkan sample test. Untuk menguji tingkat kepuasan user dan baik tidaknya layanan fasilitas yang lain, maka teknik Important Performance Analysis (IPA) digunakan untuk mengukur tingkat layanan website. Hasil penelitian menunjukkan bahwa website learning berbasis techno virtual dapat diterima secara kognitif dan menstimuli psikomotorik sehingga sangat membantu dan memudahkan mahasiswa dalam menyelesaikan tugas rekayasa visual Blender 3D.
\end{abstract}

Kata Kunci: Blender 3D, mahasiswa, techno virtual, website learning

\begin{abstract}
This applied research aims to develop a learning model of virtual media technology transfer (Techno Virtual) visual engineering Blender 3D for student-based website learning. Operationally this research will assess whether the material of teaching materials can be easily accepted through virtual techno, and help students in completing their assignments. This research uses quantitative descriptive approach, that is research based on statistical processing and controlled experiment with the sample of product design student. The analytical method used is inferencing analysis based on sample test. The Important Performance Analysis (IPA) technique is used to measure the level of website services and the level of user satisfaction. The results showed that virtual technology-based learning website can be accepted cognitively and stimulate psychomotor so it is very helpful and easier for students in completing the assignments of visual engineering Blender 3D.
\end{abstract}

Keywords: Blender 3D, student, techno virtual, website learning 


\section{PENDAHULUAN}

Memasuki era globalisasi teknologi akan informasi dan komunikasi dekade ini, sangat dirasakan betapa pentingnya pemanfaatan penerapan pembelajaran berbasis teknologi maya (techno virtual learning) dalam kegiatan pembelajaran untuk meningkatkan kualitas pembelajaran itu sendiri. Teknologi akan informasi dan komunikasi sejalan dengan munculnya perkembangan literasi teori, kecanggihan komunikasi dan teknologi yang pada akhirnya dapat menunjang terhadap praktik kegiatan pembelajaran. Techno virtual e-learning merupakan suatu sistem atau konsep pendidikan yang memanfaatkan teknologi informasi dalam proses belajar mengajar. Pembelajaran yang disusun dengan tujuan menggunakan sistem elektronik atau komputer sehingga mampu mendukung proses pembelajaran (Allen, 2013:27). Sistem pembelajaran yang digunakan sebagai sarana untuk proses belajar mengajar yang dilaksanakan tanpa harus bertatap muka secara langsung antara guru dengan siswa (Ardiansyah, 2013). Demikian juga menurut Chandrawati (2010) bahwa techno virtual e-learning merupakan proses pembelajaran jarak jauh dengan menggabungkan prinsip-prinsip dalam proses pembelajaran dengan teknologi.

Menurut Cenamo, Ross, \& Ertmer (dalam Eggen \& Kauchak 2012: 32) menyatakan bahwa dalam pembelajaran berbasis teknologi maya (techno virtual learning) bukan merupakan tujuan pembelajaran, melainkan merupakan alat yang digunakan untuk membantu peserta didik mencapai tujuan pembelajaran. Materi ajar virtual ini tidak dimaksudkan untuk menggantikan peran kehadiran dosen di studio atau lab. komputer, namun membantu mahasiswa mengembangkan pengayakan menguasai tools skill dengan mandiri tidak terkungkung oleh ruang dan waktu.

Pembelajaran tekno digital berbasis komputer, website learning, e-learning, e-teaching, sudah sangat mendesak. Berdasarkan data International Telecommunication Union (ITU), di kawasan Asia Tenggara, Indonesia hanya berada di atas Kamboja, Timor Leste, dan Myanmar. Indeks pembangunan teknologi Indonesia masih kalah dibanding dengan pemanfaatan teknologi maya di negara Singapura, Malaysia, Brunei Darussalam, Filipina, dan Vietnam (Reily, 2017).

Pembelajaran mata kuliah berbasis digital website, merupakan bagian integral platform sebuah portal akademik. Dalam pelaksanaanya membutuhkan web service, yaitu suatu fasilitas yang disediakan oleh suatu website untuk menyediakan layanan (dalam bentuk informasi) kepada sistem lain, sehingga sistem lain dapat berinteraksi dengan sistem tersebut melalui layanan-layanan (service) yang disediakan oleh suatu sistem yang menyediakan web service (Utama, 2007). Website Learning adalah pembelajaran berbasis web yang populer dengan sebutan web-based training (WBT) atau kadang disebut web-based education (WBE) dapat didefinisikan sebagai aplikasi teknologi web dalam dunia pembelajaran untuk sebuah proses pendidikan. Secara sederhana dapat dikatakan bahwa semua pembelajaran dengan memanfaatkan teknologi internet dan selama proses belajar dirasakan terjadi oleh yang mengikutinya maka kegiatan itu dapat disebut sebagai pembelajaran berbasis web. (Rusman \& Ruhimat, 2011) 
Komponen utama yang diperlukan untuk pembelajaran virtual atau virtual learning environment atau online kurikulum pendidikan antara lain: silabus mata kuliah, Administrasi informasi tentang kuliah: prasyarat kuliah semester, kredit semester, pendaftaran, pembayaran biaya kuliah, jadwal sesi pelatihan, dan informasi kontak para instruktur. Informasi tentang jadwal program yang sedang berlangsung untuk saat ini. Ujian atau perangkat analog, biasanya dicetak secara otomatis. Fitur penilaian formal, seperti ujian, pengajuan skripsi, atau presentasi projek. Dukungan untuk komunikasi secara elektronik, seperti e-mail, tweeter, massanger, FAQ, comment replay, dan unsurunsur tambahan seperti blog, RSS, e-book, wiki, termasuk bagian untuk mendukung dari portal learning ruang belajar virtual 3 dimensi. (Rouse, 2015)

Mata kuliah Rekayasa Visual Blender 3D di Program Studi Desain Produk Jurusan Desain FSR ISI Yogyakarta, merupakan salah satu mata kuliah modeling tiga dimensi dalam format digital. Blender 3D merupakan mata kuliah dasar keahlian dimana nantinya penguasaan ketrampilan atas software ini akan digunakan untuk mendasari perancangan modeling di mata kuliah berikutnya. Dalam pelaksanaan perkuliahan, secara regular dilakukan dengan model klasikal tatap muka dan tutorial lisan di lab. komputer. Selain dibatasi oleh akses penggunaan lab. komputer, juga disebabkan waktu jam praktek studio yang terbatas karena alasan operasional kampus. Hal ini cenderung membuat mahasiswa mengerjakan dan menyelesaikan tugas penuh keterbatasan dalam hal, baik sarana, ruang, waktu dan tatap muka dengan dosen.

Studi eksperimental dalam penelitian ini tengah mencoba sistem virtual learning model pembelajaran berbasis internet sehingga materi ajar dapat dipelajari ulang dengan seksama oleh mahasiswa tanpa dibatasi ruang dan waktu karena medium bahan ajar yang tersimpan secara digital. Guna memberi akses yang lebih luas dan memberikan peluang dalam mempelajari materi lebih dalam, kompleks dan utuh serta menstimuli psikomotorik mahasiswa baik secara kualitas maupun kuantitas dalam menyelesaikan tugas dengan software Blender 3D, untuk itu maka disusunlah materi bahan ajar dalam bentuk techno virtual berbasis website learning. Penelitian ini ditujukan untuk menguji apakah model pembelajaran techno virtual berbasis website learning dapat membantu penguasaan materi sekaligus meningkatkan produktivitas baik kualitas dan kreativitas karya desain mahasiswa.

Pembahasan tentang open source software Blender 3D ini, pernah dibahas oleh Mochamad Faizal Rochman (2013), dengan judul Blender 3D untuk Pendidikan Animasi, menyampaikan pandangannya dan untuk memastikan bahwa penggunaan perangkat lunak Open Source Gratis (FOSS) Blender 3D sangat cocok untuk diterapkan di dunia pendidikan sebagai pengantar untuk mempelajari animasi tiga dimensi. Paparan selanjutnya adalah penelitian Kurniawan, Akbar Indra (2014) berjudul Pembuatan Model dan Animasi 3D Tubuh Manusia untuk Pembelajaran Anak SD Kelas 4-6, menyampaikan pula pandangannya tentang bagaimana membuat modul virtual digital model dan animasi 3D yang praktis untuk mempermudah anak-anak SD kelas 4 - 6 dalam mempelajari anatomi tubuh manusia. Disini dapat disimpulkan bahwa, melalui hasil penelitian mereka dapat ditarik benang merah bahwa media pembelajaran virtual dan 
3D Blender dapat digunakan sebagai sarana pembelajaran dalam dunia pendidikan.

Sedangkan pemanfaatan teknologi pembelajaran maya telah dibahas oleh Bibit Sih Handoko, Guru SMK Negeri 1 Turen Kabupaten Malang, dengan judul penelitiannya: Teknologi Informasi dan Komunikasi untuk Meningkatkan Kualitas Pembelajaran. Dalam paparannya menekankan bahwa penerapan pembelajarn berbasis Internet atau yang lebih dikenal dengan e-learning atau virtual learning merupakan salah satu contoh pemanfaatan TIK dalam pembelajaran. Secara komprehensif, makalah tersebut juga membahas tentang pengertian, kelebihan dan keterbatasan, serta kondisi yang diperlukan agar penerapan pembelajaran berbasis Internet (virtual learning) dapat berhasil. Pembahasan tentang virtual learning tersebut akan di awali dengan perkembangan pemanfaatan TIK dalam pembelajaran.

Penelitian lain dengan judul: Kegiatan Belajar Mengajar Dengan Metode Virtual Learning, disajikan oleh Amatus Yudi Ismanto dari Program Magister Kekhususan Anak Fakultas IImu Keperawatan Universitas Indonesia, 2010. Memaparkan pandangannya bahwa teknologi virtual e-learning salah satunya adalah menawarkan bahwa pembelajaran ini secara aktif dilakukan oleh objek peserta didik. Aplikasi dalam virtual learning memberikan kesempatan kepada pelajar untuk belajar mengembangkan pengetahuan dan ketrampilannnya dengan tidak ada keterbatasan. Di dalam virtual learning pendidik menggunakan pendekatan yang berbeda dan akses internet dengan bandwitch yang memadai adalah sangat dibutuhkan. Faktor lain yang berhubungan dengan sukses atau tidaknya dari keberadaan dengan metode virtual learning ini, secara mutlak menyangkut ketersediaan literatur dan dukungan atmosphere academic secara ilmiah, di dalamnya menyangkut faklor lain, antara lain adalah tersedianya silabus mata kuliah, Satuan Acara Perkuliahan (SAP), dan yang penting lagi adalah partisipan dosen mengajar secara aktif.

\section{METODOLOGI PENELITIAN}

Penelitian terapan adalah salah satu jenis penelitian yang bertujuan untuk memberikan solusi atas permasalahan tertentu secara praktis. Penelitian ini tidak berfokus pada pengembangan sebuah ide, teori, atau gagasan, tetapi lebih berfokus kepada penerapan penelitian tersebut dalam kehidupan sehari-hari. Ciri utama dari penelitian ini adalah tingkat abstraksi yang rendah, dan manfaat atau dampaknya dapat dirasakan secara langsung (Maryati, Kun. 2015). Pendekatan penelitian kuantitatif adalah metode penelitian yang menekankan pada fenomena-fenomena yang objektif dan digunakan untuk meneliti pada populasi atau sampel-sampel tertentu, teknik pengambilan sampel pada umumnya dilakukan secara random, pengumpulan data menggunakan instrument penelitian, analisis data bersifat kuantitatif/statistik dengan tujuan untuk menguji hipotesis yang ditetapkan (Machmud, 2016). Statistik deskriptif adalah statistik yang digunakan untuk menganalisis data dengan cara mendeskripsikan atau menggambarkan data yang telah terkumpul sebagaimana adanya tanpa bermaksud membuat kesimpulan yang berlaku untuk umum atau generalisasi. (Sugiyono, 2012) 
Hipotesis yang diajukan adalah bahwa website learning berbasis techno virtual dapat diterima secara kognitif dan menstimuli psikomotorik sehingga membantu dan memudahkan mahasiswa dalam menyelesaikan tugas rekayasa visual Blender 3D.

\section{HASIL DAN PEMBAHASAN}

\subsection{Pengumpulan Data}

Data dikumpulkan dengan observasi lapangan dan kuisioner, adapun penerapannya menggunakan observasi sistematis yaitu observasi yang sudah ditentukan terlebih dahulu kerangkanya. Kerangka tersebut memuat faktor-faktor yang akan diobservasi menurut kategorinya. (Rahayu \& Ardani, 2004)

Dari persiapan yang dilakukan maka diperoleh paparan data sebagai berikut:

1. Laman website ISI Yogyakarta

Adalah halaman digital awal website yang akan selalu muncul setiap personal ingin masuk ke dalam materi bahan ajar.

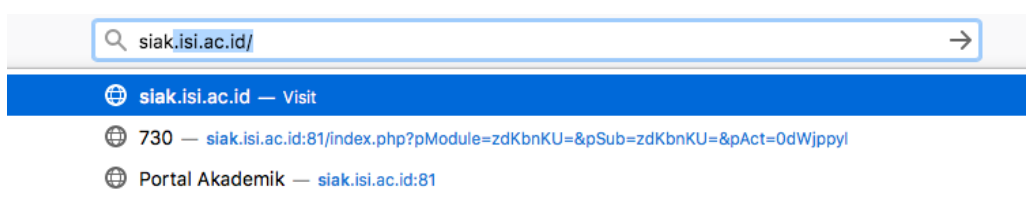

Gambar 1. Tampilan awal platform PHP- MySQL Website ISI Yogyakarta

2. User interface Portal Akademik ISI Yogyakarta

Adalah halaman digital Portal Akademik adalah sistem yang memungkinkan para civitas akademika Institut Seni Indonesia Yogyakarta untuk menerima informasi dengan lebih cepat melalui Internet. Sistem ini diharapkan dapat memberi kemudahan setiap civitas akademika untuk melakukan aktivitas-aktivitas akademik dan proses belajar mengajar.

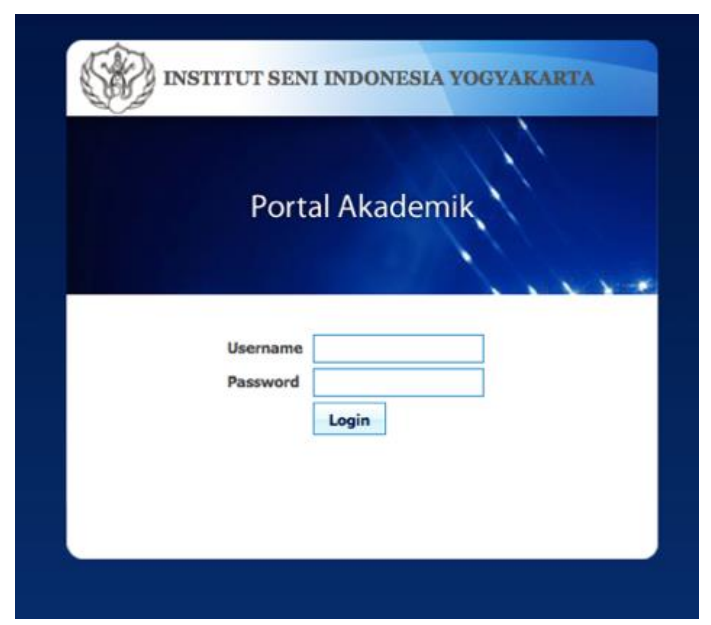

Gambar 2. Tampilan user interface portal akademik ISI Yogyakarta 
3. User interface laman web akademik

Adalah cover halaman digital utama yang mengantar user berselancar mencari objek yang dibutuhkan.

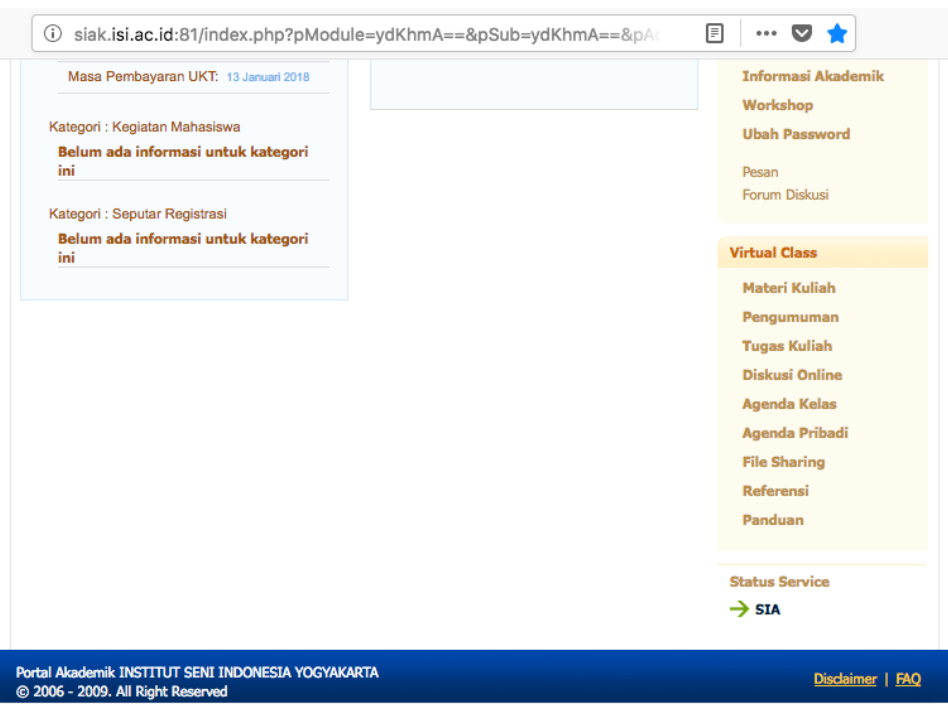

Gambar 3. Tampilan user interface laman akademik ISI Yogyakarta

\section{User interface tutorial Blender 3D}

Adalah halaman digital yang berisi tutorial terstruktur dan berurutan dimulai dari materi dasar pembuatan objek gambar manual hingga ke bentuk 3D. Tugas selanjutnya mengarah ke bentuk objek yang lebih rumit dan fiture skin, efek dan animasi.

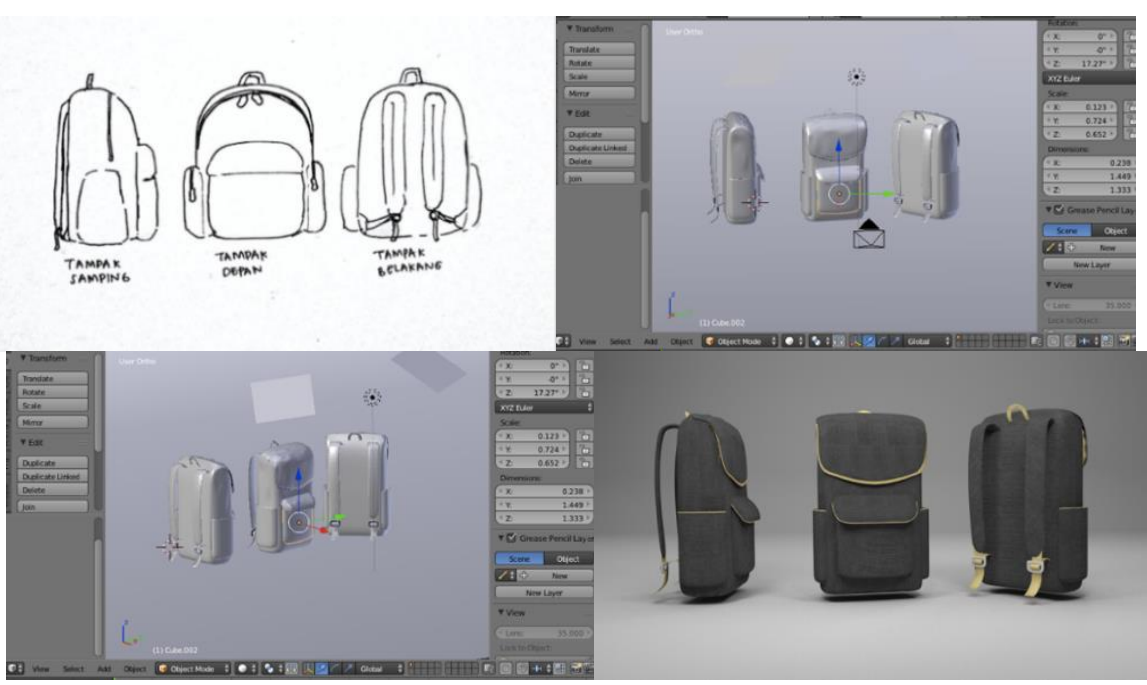

Gambar 4. Tampilan salah satu modul pertemuan kuliah virtual, berisi tutorial sejak gambar manual hingga fill masking skin. 
5. User interface tugas rekayasa visual

Adalah halaman digital yang berisi aneka tugas menyusun objek rekayasa visual selama 1 semester termasuk UTS dan UAS.

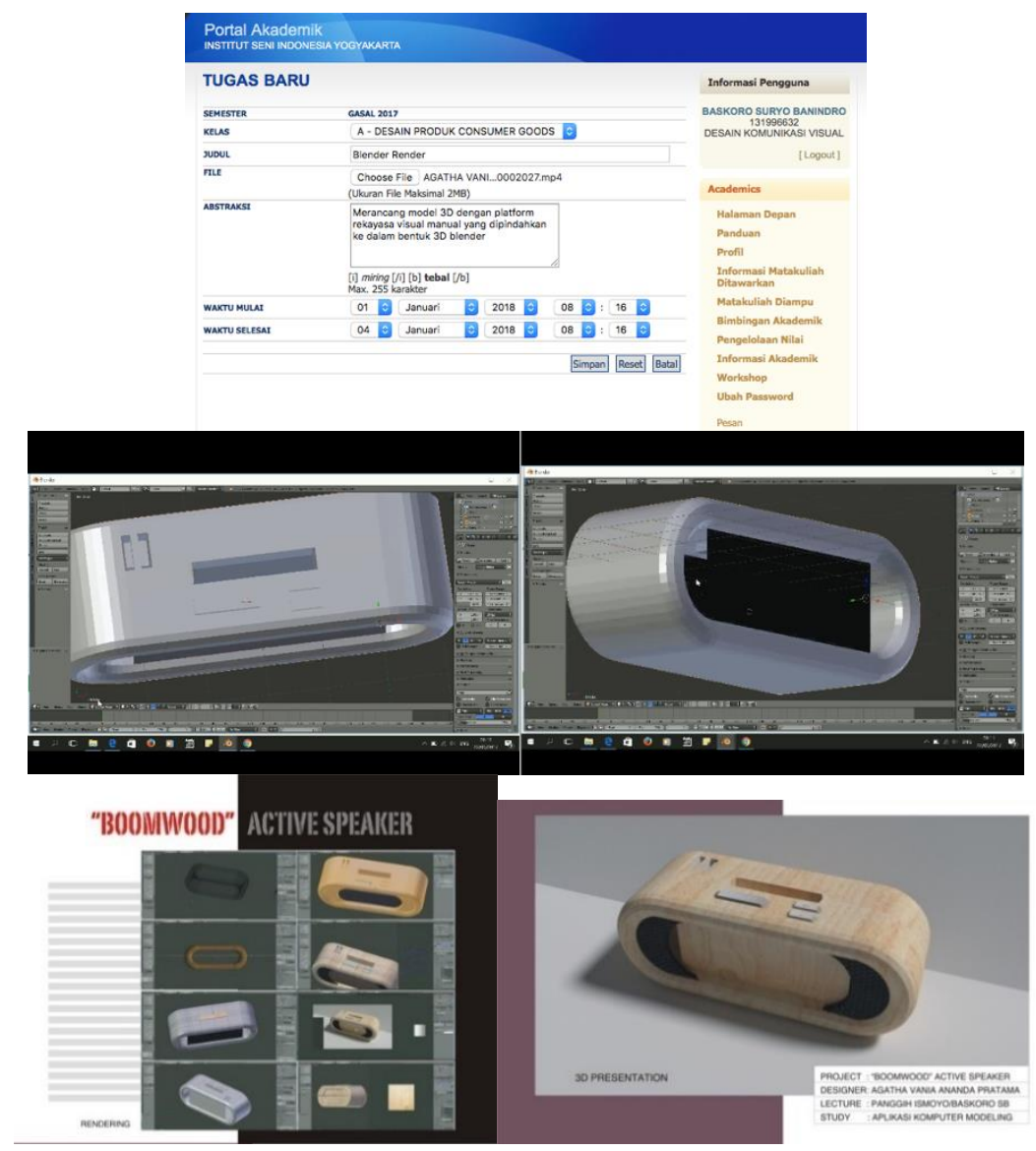

Gambar 5. Tampilan salah satu tugas dari pertemuan kuliah virtual, dimulai dari unduh tugas hingga mahasiswa mengupload file proses pembuatan modeling dan tampilan akhir desain grafis produknya.

6. User interface nilai tugas

Adalah halaman yang mengetengahkan nilai akhir tugas mahasiswa.
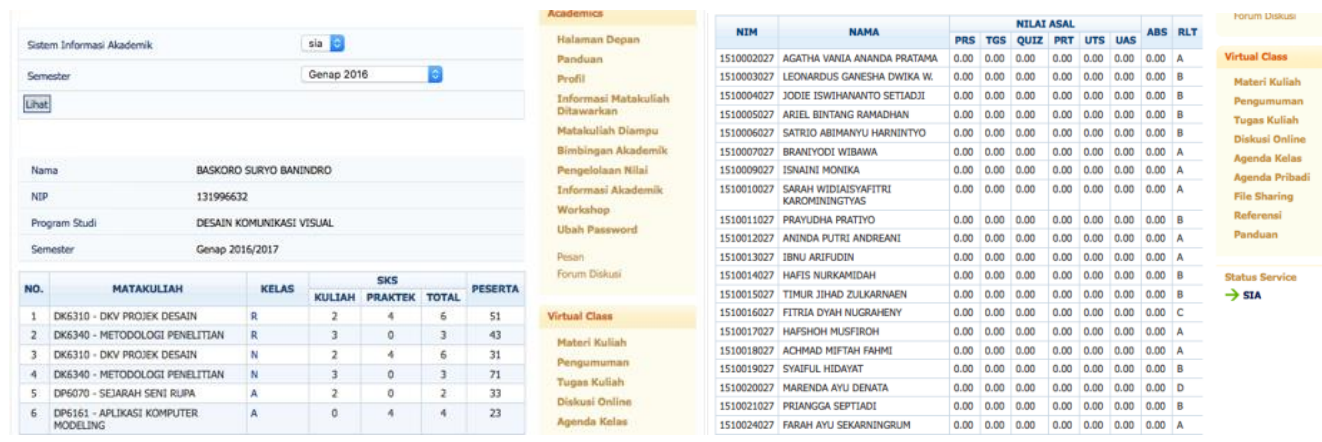

Gambar 6. Tampilan nama peserta kuliah dan rekap nilai tugas dalam 1 semester. 


\subsection{Analisis Data}

Data akan dianalisis secara deskriptif kuantitatif, dimana sifat penelitian ini merupakan penelitian yang bertujuan menjelaskan fenomena yang ada dengan menggunakan angka-angka untuk memaparkan karakteristik individu atau kelompok (Syamsudin \& Damiyanti, 2011)

Lembar observasi dalam objek kuisioner berupa pertanyaan:

1. User interface website ISI Yogyakarta

Dari kuisioner yang diberikan kepada mahasiswa peserta kuliah Rekayasa Visual Blender 3D, objek yang ditanyakan apakah cukup mudah untuk mengindikasikan laman website ISI Yogyakarta.

2. User interface portal akademik ISI Yogyakarta

Kuisioner kepada para mahasiswa menyangkut pola kepraktisan dalam membaca atau mencari kolom isian yang dikehendaki sebelum masuk ke menu utama materi bahan ajar virtual Blender 3D.

3. User interface laman virtual learning Blender 3D

Kuisioner menanyakan seberapa nyaman dan familiar dalam mencermati menu laman materi ajar.

4. User interface tutorial Blender 3D

Kuisioner secara komprehensif menanyakan tentang seberapa jauh mahasiswa dapat memahami isi tutorial guide materi Blender 3D, sekaligus akses FAQ (Frequently Ask Question) bagi dosen.

5. User interface tugas rekayasa visual

Kuisioner berisi pertanyaan apakah mahasiswa dapat dengan mudah mengupload tugas dalam format yang telah ditetapkan dengan ukuran file maksimal.

\subsection{Pembahasan}

Dalam penelitian perancangan sistem ini, maka telah dilakukan pengujian sistem melalui uji publik dalam hal ini para mahasiswa dalam skala terbatas. Dengan web hosting inisial: siak.isi.ac.id yang dikelola oleh UPT Puskom ISI Yogyakarta, uji media dilakukan terhadap mahasiswa Program Studi Desain Produk FSR ISI Yogyakarta, sebagai populasi adalah data mahasiswa angkatan 2015 yang menempuh kuliah aktif semester Genap 2016 dan sample adalah para mahasiswa yang mengambil mata kuliah Rekayasa Visual Blender 3D.

Analisis diperoleh melalui angka dalam bentuk deskriptif persentase atas 23 mahasiswa yang mengikuti perkuliahan Rekayasa Visual Blender 3D melalui portal akademik website: siak.isi.ac.id dapat diperoleh data kualitatif dari para mahasiswa bahwa website learning techno virtual interaktif ini dapat membantu mahasiswa dalam mengerjakan tugas secara mandiri berpedoman tutorial dan penugasan. Untuk menguji tingkat kepuasan user dan baik tidaknya layanan fasilitas yang lain, maka teknik Important Performace Analysis (IPA) digunakan untuk mengukur tingkat layanan website. (Martilla \& James, 1977) 


$$
P=\frac{F}{N} x 100 \%
$$

Keterangan

$\mathrm{P}=$ Persentase yang dicari

$\mathrm{F}=$ Frekuensi yang sedang dicari

$\mathrm{N}=$ Jumlah skor maksimum

Dari perhitungan dengan menggunakan rumus di atas maka dapat diklasifikasikan sebagai berikut:
a. Indeks Layanan > $100 \%$ berarti sangat baik/memuaskan
b. Indeks Layanan $76 \%$ - 99\% berarti baik/memuaskan
c. Indeks Layanan $50 \%$ - 75\% berarti cukup baik/memuaskan
d. Indeks Layanan $40 \%$ - 55\% berarti tidak baik/memuaskan
e. Indeks Layanan $<40 \%$ berarti sangat tidak baik/memuaskan

Tabel 1. Indeks layanan laman website ISI Yogyakarta

\begin{tabular}{|c|l|c|l|}
\hline No & \multicolumn{1}{|c|}{ Indikator Aspek } & Persentase & \multicolumn{1}{|c|}{ Kategori } \\
\hline 1 & Waktu loading singkat & $98 \%$ & Baik \\
\hline 2 & Tidak ada broken link & $97 \%$ & Baik \\
\hline 3 & Website bisa di akses tanpa $w w w$ & $100 \%$ & Sangat Baik \\
\hline 4 & URL user friendly & $100 \%$ & Sangat Baik \\
\hline
\end{tabular}

Dari kuisioner yang diberikan kepada mahasiswa peserta kuliah Blender 3D Rekayasa Visual, objek yang ditanyakan apakah cukup mudah untuk mengindikasikan laman website ISI Yogyakarta? maka tercapai skor 98\%, yang mengindikasikan bahwa mahasiswa tidak mendapat hambatan saat memulai melakukan aktivitas terkait bahan ajar.

Tabel 2. Indeks layanan user interface portal akademik ISI Yogyakarta

\begin{tabular}{|c|l|c|l|}
\hline No & \multicolumn{1}{|c|}{ Indikator Aspek } & Persentase & \multicolumn{1}{|c|}{ Kategori } \\
\hline 1 & Desain Cover & $85 \%$ & Baik \\
\hline 2 & Desain Grafis & $80 \%$ & Baik \\
\hline 3 & Brand Lembaga & $90 \%$ & Baik \\
\hline 4 & Portal Login & $100 \%$ & Sangat Baik \\
\hline
\end{tabular}

Kuisioner kepada para mahasiswa menyangkut pola kepraktisan dalam membaca user interface portal login, sebelum masuk ke menu utama materi bahan ajar virtual Blender 3D? mahasiswa memberikan skor $88 \%$, hal ini menunjukkan user interface portal akademik baik dan familiar. 
Tabel 3. Indeks layanan user interface laman virtual learning Blender 3D

\begin{tabular}{|c|l|c|l|}
\hline No & \multicolumn{1}{|c|}{ Indikator Aspek } & Persentase & \multicolumn{1}{|c|}{ Kategori } \\
\hline 1 & Navigasi & $100 \%$ & Sangat Baik \\
\hline 2 & Basic Operating & $100 \%$ & Sangat Baik \\
\hline 3 & Blender Cycles & $100 \%$ & Sangat Baik \\
\hline 4 & Point, Edge, Triangle, dan Mesh & $99 \%$ & Baik \\
\hline
\end{tabular}

Kuisioner menanyakan seberapa nyaman dan familiar dalam mencermati menu laman website utama? mahasiswa memberikan skor $99 \%$, hal ini menunjukkan bahwa mereka tidak kesulitan dalam memahami awal mempelajari Blender 3D.

Tabel 4. Indeks layanan user interface tutorial Blender 3D

\begin{tabular}{|c|l|c|l|}
\hline No & \multicolumn{1}{|c|}{ Indikator Aspek } & Persentase & \multicolumn{1}{|c|}{ Kategori } \\
\hline 1 & Material and Texture & $100 \%$ & Sangat Baik \\
\hline 2 & Modifier Subdivision Surface & $100 \%$ & Sangat Baik \\
\hline 3 & Camera & $90 \%$ & Baik \\
\hline 4 & Animation & $95 \%$ & Baik \\
\hline
\end{tabular}

Kuisioner secara komprehensif menanyakan tentang seberapa jauh mahasiswa dapat memahami dalam mengikuti tutorial materi Blender 3D? skor 96\%, diberikan oleh para mahasiswa yang menilai bahwa tutorial Blender 3D ini sangat membantu (helpful) dalam menyelesaikan tugas yang diberikan dosen.

Tabel 5. Indeks layanan user interface uploader tugas Blender 3D

\begin{tabular}{|c|l|c|l|}
\hline No & \multicolumn{1}{|c|}{ Indikator Aspek } & Persentase & \multicolumn{1}{|c|}{ Kategori } \\
\hline 1 & Kapasitas File & $98 \%$ & Memuaskan \\
\hline 2 & Loading Upload & $98 \%$ & Memuaskan \\
\hline 3 & Penanganan error & $100 \%$ & $\begin{array}{l}\text { Sangat } \\
\text { Memuaskan }\end{array}$ \\
\hline 4 & Automatic Replace & $100 \%$ & $\begin{array}{l}\text { Sangat } \\
\text { Memuaskan }\end{array}$ \\
\hline
\end{tabular}

Kuisioner berisi pertanyaan apakah mahasiswa dapat dengan mudah mengupload tugas dan solusi atas hambatan yang muncul ? para mahasiswa memberikan skor $99 \%$, yang mengindikasikan bahwa mahasiswa tidak mendapatkan kesulitan saat mereka harus mengupload tugas mata kuliah Blender 3D ke dosen. 
Tabel 6. Indeks layanan capaian tugas Blender 3D

\begin{tabular}{|c|l|c|l|}
\hline No & \multicolumn{1}{|c|}{ Indikator Aspek } & Skor & \multicolumn{1}{|c|}{ Kategori } \\
\hline 1 & Tugas harian & $99 \%$ & Baik \\
\hline 2 & Ujian Tengah Semester & $100 \%$ & Sangat Baik \\
\hline 3 & Projek Desain & $100 \%$ & Sangat Baik \\
\hline 4 & Ujian Akhir Semester & $99 \%$ & Baik \\
\hline
\end{tabular}

Dari indikator skor 99\% di atas, dapat diperoleh kesimpulan bahwa dengan adanya materi dan media bahan ajar teknologi maya (techno virtual learning) melalui web portal akademik, kuantitas nilai dan hasil karya yang dihasilkan para mahasiswa sangat signifikan.

Hasil review kuantitatif diperoleh vailidasi persentase dari ahli konten materi Blender 3D atas materi kuliah rekayasa vsual kategori sangat baik memperoleh persentase sebesar $100 \%$, hal ini berarti isi/materi yang disajikan dalam website learning telah sesuai silabus perkuliahan. Persentase atas bobot tutorial Blender 3D menurut ahli multimedia sebesar 99\%. Hasil review ahli multimedia yang digunakan untuk menilai kerelevanan media yang digunakan dengan user interface content bahan ajar sebesar $100 \%$, masih berada dalam kategori sangat baik. Hasil review ahli desain pembelajaran virtual learning menunjukkan tingkat kognisi materi ajar website learning yang dikembangkan memperoleh presentase sebesar $100 \%$, berada dalam kategori baik. Secara keseluruhan hasil review para pakar pendidikan dan multimedia menunjukkan nilai yang sangat bagus.

Tabel 7. Indeks layanan konten materi Blender 3D

\begin{tabular}{|c|l|c|l|}
\hline No & \multicolumn{1}{|c|}{ Indikator Aspek } & Persentase & \multicolumn{1}{|c|}{ Kategori } \\
\hline 1 & Materi Kuliah Rekayasa Visual & $100 \%$ & Sangat Baik \\
\hline 2 & User Interface Content & $100 \%$ & Sangat Baik \\
\hline 3 & Kognisi Materi Ajar & $100 \%$ & Sangat Baik \\
\hline 4 & Bobot Tutorial 3D Blender & $99 \%$ & Baik \\
\hline
\end{tabular}

\section{KESIMPULAN}

Globalisasi digital bukan merupakan hal yang baru lagi di abad ini, sejak awal perkembangannya telah begitu cepat menghasilkan inovasi dan pengetahuan yang mengagumkan secepat celeritas cahaya bagi kehidupan bagi manusia. Dunia pendidikan sebagai pintu gerbang masuknya ilmu pengetahuan, selalu terbuka dengan hadirnya invensi yang mendukung dan berguna bagi kemajuan sain dan teknologi. Internet telah membuka cara pandang baru dalam membaca cakrawala pengetahuan berbasis digital, melalui teknologi maya jutaan cyber aplikasinya telah dirasakan manfaatnya. 
Penelitian pengembangan techno virtual berbasis website sebagai media pembelajaran bagi mahasiswa, merupakan salah satu aplikasi terapan dari teknologi digital e-learning. Alih wahana media digital ini dirancang tidak untuk menggantikan peran pengajar dan memindahkan suasana akademik secara permanen ke dalam dimensi cyber space, namun media pembelajaran elektronik ini merupakan suplemen bagi mahasiswa untuk mengembangkan dan mengasah kemampuan secara mandiri dengan panduan instruksional berbasis digital.

Melalui serangkaian uji coba virtual, maka media pembelajaran pada mata kuliah Rekayasa Visual software Blender 3D melalui website portal akademik ini, telah dapat membantu para mahasiswa dalam menyelesaikan tugas modeling terkait desain produk. Pedoman penyusunan materi kuliah pembelajaran teknologi maya ini, tetap melandaskan pada silabus dan Satuan Acara Perkuliahan (SAP), sehingga mahasiswa tetap dapat dengan tertib menyelesaikan tugas, try and develop dalam penguasaan fitur dan fasilitas.

Melalui hasil analisis data dan sintess, uji publik terbatas dan review ahli, maka website learning berbasis techno virtual dapat dijadikan formula bahan ajar teknologi maya, sehingga membantu dan memudahkan mahasiswa dalam menyelesaikan tugas rekayasa visual Blender 3D.

Dalam mengembangkan techno virtual berbasis website media pembelajaran rekayasa visual, sebagai salah satu aplikasi terapan dari teknologi digital e-learning, tidak dirancang untuk menggantikan peran pengajar dan memindahkan metode pengajaran dengan cara pandang baru. Metode pengajaran berbasis virtual dirancang untuk memberikan keleluasaan kepada para mahasiswa dalam memperpanjang waktu menyelesaikan tugas di luar studio dengan tidak mengurangi substansi dan kompetensi materi yang dipelajari. Perlu diingat bahwa penyusunan metode pengajaran tetap mengacu pada kisi-kisi pembelajaran konvensional, pengembangan techno virtual berbasis website bukan merupakan tutorial praktis, namun tetap mengedepankan tujuan instruksional sebagai pedoman pendidikan dan pengajaran di dalamnya.

\section{DAFTAR PUSTAKA}

Allen, M. (2013). Michael Allen's Guide to E- learning. Canada: John Wiley \& Sons.

Chandrawati, Sri Rahayu (2010), Pemanfaatan E-learning dalam Pembelajaran. No 2 Vol. 8. http://jurnal.untan.ac.id

Eggen, Paul \& Kauchak, Don. (2012). Strategi dan Model Pembelajaran: Mengajarkan Konten dan Keterampilan Berfikir. Jakarta: Indeks.

Machmud, Muslimin. 2016. Kerangka Sistematika Format Penulisan Tugas Akhir. Malang: Penerbit Selaras

Martilla \& J. C. James, (1977), "Importance Performance Analysis," Journal of Marketing Maryati, Kun. (2015), Sosiologi: Jilid 3. Jakarta: ESIS. Hal 103. ISBN 979-734-529-7, 9789797345297.

Rahayu, lin Tri, dan Ardani, Tristiadi Ardi, (2004). Observasi dan Wawancara. Malang: Bayumedia. 
Reily, M. (2017). Teknologi Informasi di Indonesia Peringkat 111 dari 176 Negara. Retrieved February 27, 2019, from https://katadata.co.id/berita/2017/12/15/teknologi-informasi-di-indonesiaperingkat-111-dari-176-negara

Rouse, M. (2015). What is virtual learning environment (VLE) or managed learning environment (MLE)? - Definition from Whatls.com. Retrieved February 27, 2019, from https://whatis.techtarget.com/definition/virtual-learningenvironment-VLE-or-managed-learning-environment-MLE

Rusman \& Ruhimat, Toto. 2011. Layanan Pembelajaran Berbasis E-Learning Untuk Pemerataan Akses Dan Peningkatan Mutu Pendidikan. diakses Senin, 28 Februari 2011

Sugiyono (2012) Metodologi Penelitian Pendidikan Pendekatan Kuantitatif, Kualitatif dan $R$ \& D. Bandung: CV. Alfabeta

Syamsuddin, dkk. (2011) Metode Penelitian Pendidikan Bahasa. Bandung: PT. Remaja Rosdakarya.

Utama, Yadi . (2007). Teknik Pemrograman Web Service PHP Dengan Menggunakan SOAP dan WSDL, jbptunikompp-gdl-zachman-25650-12-webserv-I.doc 